
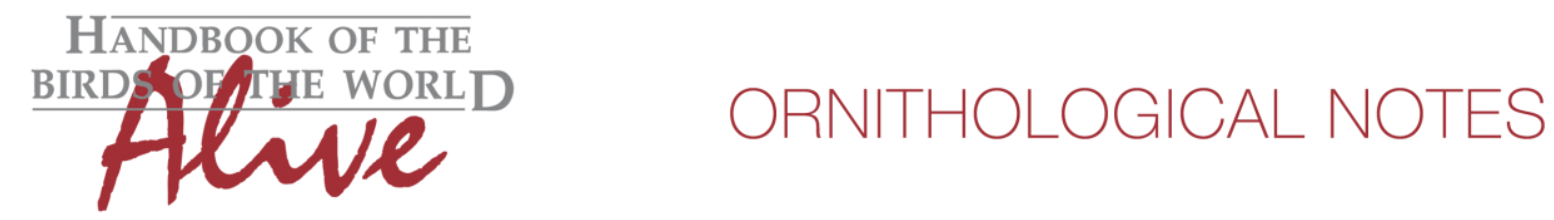

\title{
Notes on the vocalizations of Hair-crested Drongo (Dicrurus hottentottus)
}

Peter Boesman

In the following we briefly analyze and compare voice of the different races of Hair-crested Drongo (Dicrurus hottentottus). We also try to quantify the extent of any vocal differences using the criteria proposed by Tobias et al. (2010), as a support for taxonomic review.

We have made use of sound recordings available on-line from Xeno Canto (XC), Macaulay Library (ML) and Avian Vocalizations Center (AVoCet).

With fourteen subspecies of which many confined to single islands, the wide vocabulary in this group and hardly any guiding indication based on morphology, this is obviously a very complex case, to say the least. This note is therefore rather a preliminary analysis, based on available recordings.

We have looked-up all available recordings of Hair-crested Drongo, Sumatran Drongo $D$. sumatranus and Sulawesi Drongo D. montanus. We have searched for all different vocalisation types and copied the sonograms under every taxon or group of taxa (see Annex 1).

From these recordings, some first observations:

* The set of sonograms is different for every group, no set is about identical. The answer to the simple question 'Is voice different?' is YES. But with every additional recording we get an additional new vocalisation in about half the cases, thus the vocabulary of every group is still wider than what we have accumulated here (and which is already quite extensive...).

* We could either look for differences between groups (with the eternal pitfall that absence of recordings is not the same as absence of this vocalization), or we could look for similarities, which then is a fact, but with a similar weakness that in absence of a full vocabulary we only get a partial picture of similarities...

* It is clear that in any case, the Tobias criteria are hardly fit to evaluate here the difference in vocabulary, for the simple reason that it is absolutely unclear which are homologous vocalizations. If as a first approximation, we would compare the basic sound parameters of the entire vocabulary combined, then (given the wide variation within a group (even an individual) with vocalizations covering a wide range of the frequency spectrum etc.) these would be for every group about the same, leading to (very) low scores, which are of little use.

* As a side note, one can obviously also question whether in case of oscine passerines which are capable of delivering such a wide variety of sounds of which some likely are imitations, which vocalizations are the ones that are significant in pair-forming and that consequently could work as a barrier for gene flow if significantly different. How important is the fact that e.g. a few of the many notes/phrases are seemingly unique. How does it work for these birds?

In order to find some possible patterns, we have defined 12 'note types' (or short phrases) found in the recordings, and we noted down which group uses which note types. These types are: 1 . a scratchy grating note followed by a whistle, 2 . a sharply downslurred or upslurred whistle, 3. a long whistle only slightly downslurred or upslurred, 4. an overslurred whistle with a rounded top, 


\section{HANDBOOK OF THE \\ wropt \\ Alve}

5. a very short note showing as a dot on a sonogram, 6 . a short scratchy note, 7 . fast repeats of the same note, 8 . a nasal note showing as parallel horzontal lines on a sonogram, 9. a drawn-out scratchy scolding note, 10 . an overslurred note with a flat top, 11 . a $V$-shaped note, 12 . a fast jumbling of short notes at different pitch. We made a quick hand-written table illustrating the note shapes in the first row:

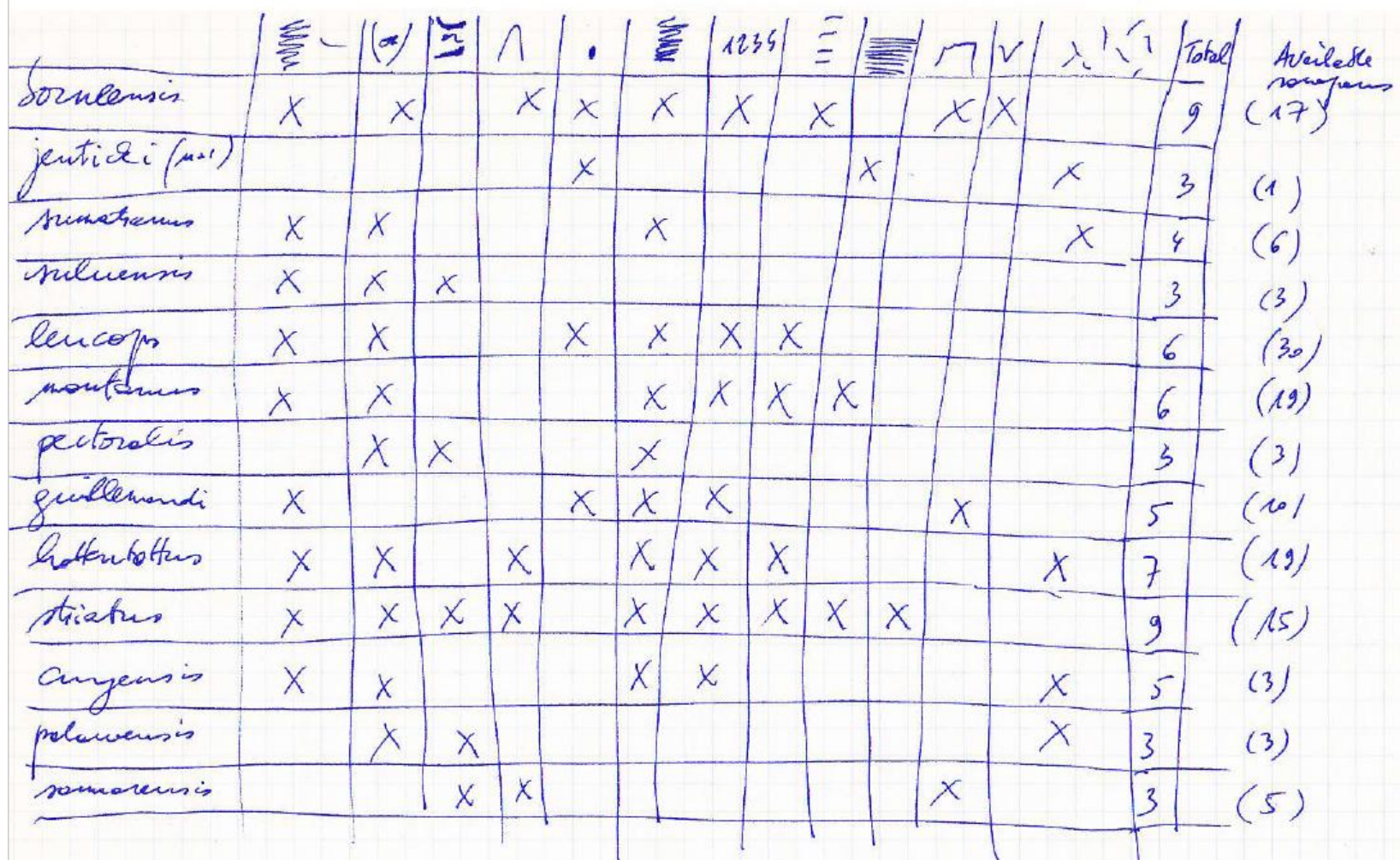

It is clear from this table that the groups with the highest number of note types are mainly the groups for which there are most recordings (last column), which confirms somewhat the presumption that vocabulary is wider than what we have accumulated sofar.

The Philippine group (palawensis, cuyensis??, samarensis, striatus, suluensis) seem to be the only ones often using fairly long notes at about flat pitch (note type 3 ) (the single example of pectoralis being quite different).

The Sunda group (borneensis, jenticki, leucops, guillemardi, pectoralis??) seem to be the only ones often using short and sharp 'point-like' notes (note type 5). It is also clear that the difference between parapatric montanus and leucops seems to lie mainly in these notes. This group also seems to lack the use of overslurred notes (note type 4), except for borneensis.

The use of grating and/or nasal notes is rather universal, possibly less frequent in the Philippine group. 

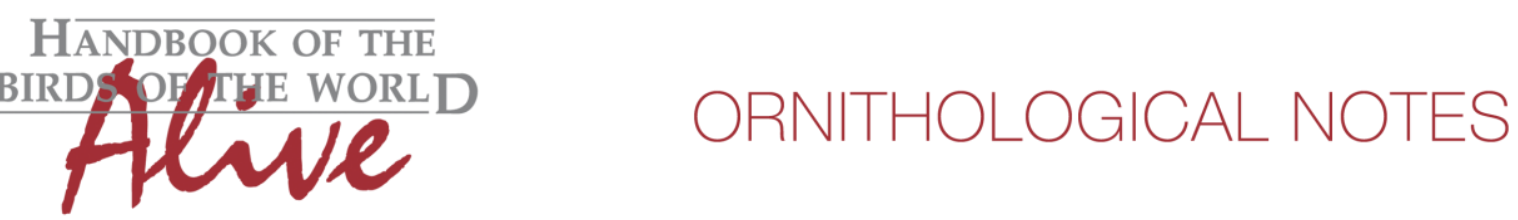

If we would have to make a grouping based on voice, which clearly is a horrendous task at present, we would put forward based on at least some proven constant structural difference in voice:

* The mainland group (lacking point-like and slurred notes). The Sumatran Drongo (assuming it lacks indeed the point-like notes), is vocally not substantially different.

* The Philippine group (for having slurred whistles)

*The Sunda group (for having point-like notes)

* The montanus race (assuming it lacks indeed the point-like notes)

It is clear that more study work will be needed to get a better understanding in the vocalizations and possible differences of this complex group.

This note was finalized on 7th March 2016, using sound recordings available on-line at that moment. We would like to thank in particular the many sound recordists who placed their recordings for this species on XC, ML and AVoCet.

\section{References}

Tobias, J.A., Seddon, N., Spottiswoode, C.N., Pilgrim, J.D., Fishpool, L.D.C. \& Collar, N.J. (2010). Quantitative criteria for species delimitation. Ibis 152(4): 724-746.

\section{Recommended citation}

Boesman, P. (2016). Notes on the vocalizations of Hair-crested Drongo (Dicrurus hottentottus). HBW Alive Ornithological Note 191. In: Handbook of the Birds of the World Alive. Lynx Edicions, Barcelona. (retrieved from http://www.hbw.com/node/932135 on 26 August 2016). 


\section{HANDBOOK OF THE BIRDSPFGE WORLD}

\section{ORNITHOLOGICAL NOTES}

Annex 1: Sonograms of all distinct vocalizations found in the recordings, grouped per race.

\section{D.h. borneensis (Borneo)}

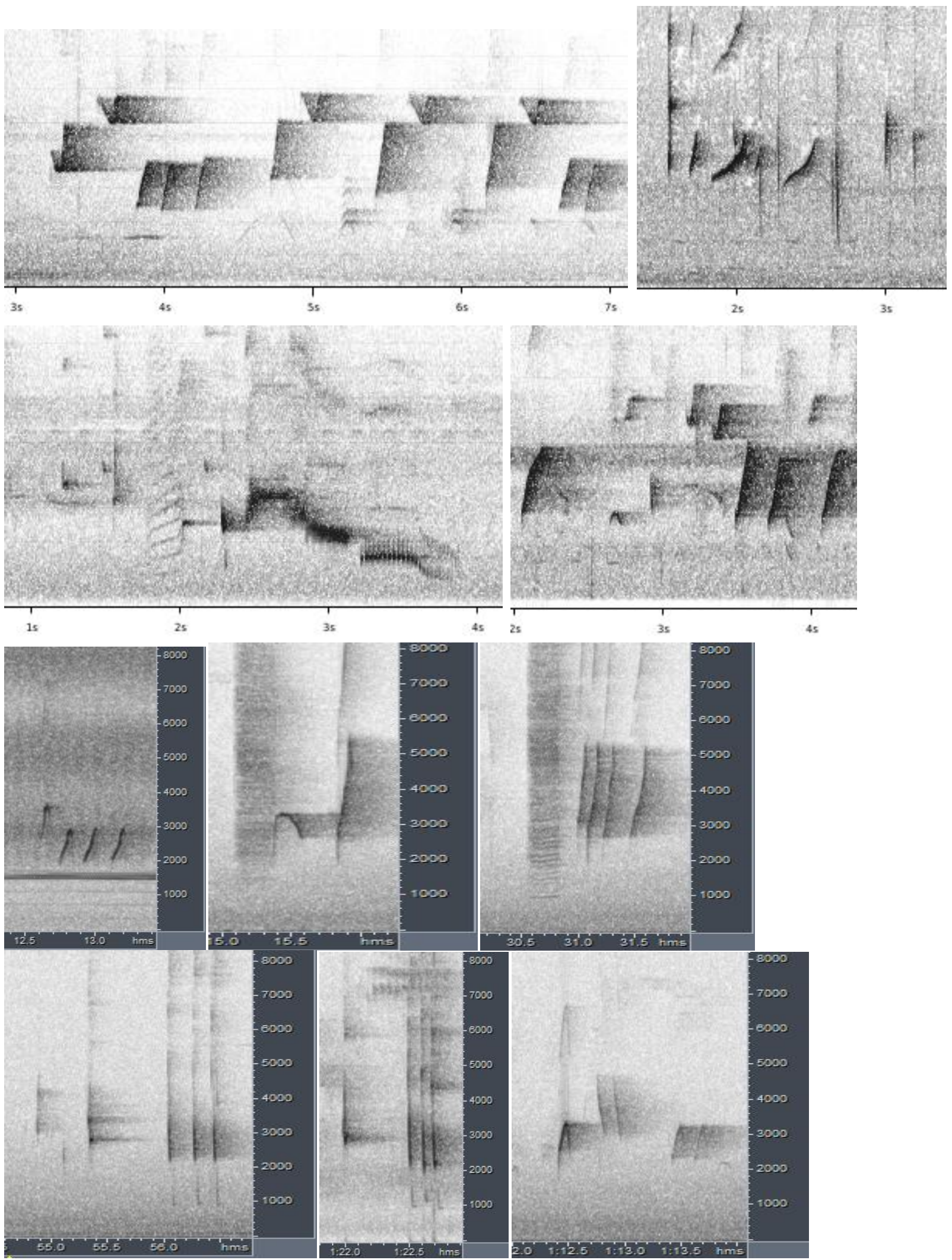


HANDBOOK OF THE

BIRDSPF TUE WORLD

ORNITHOLOGICAL NOTES
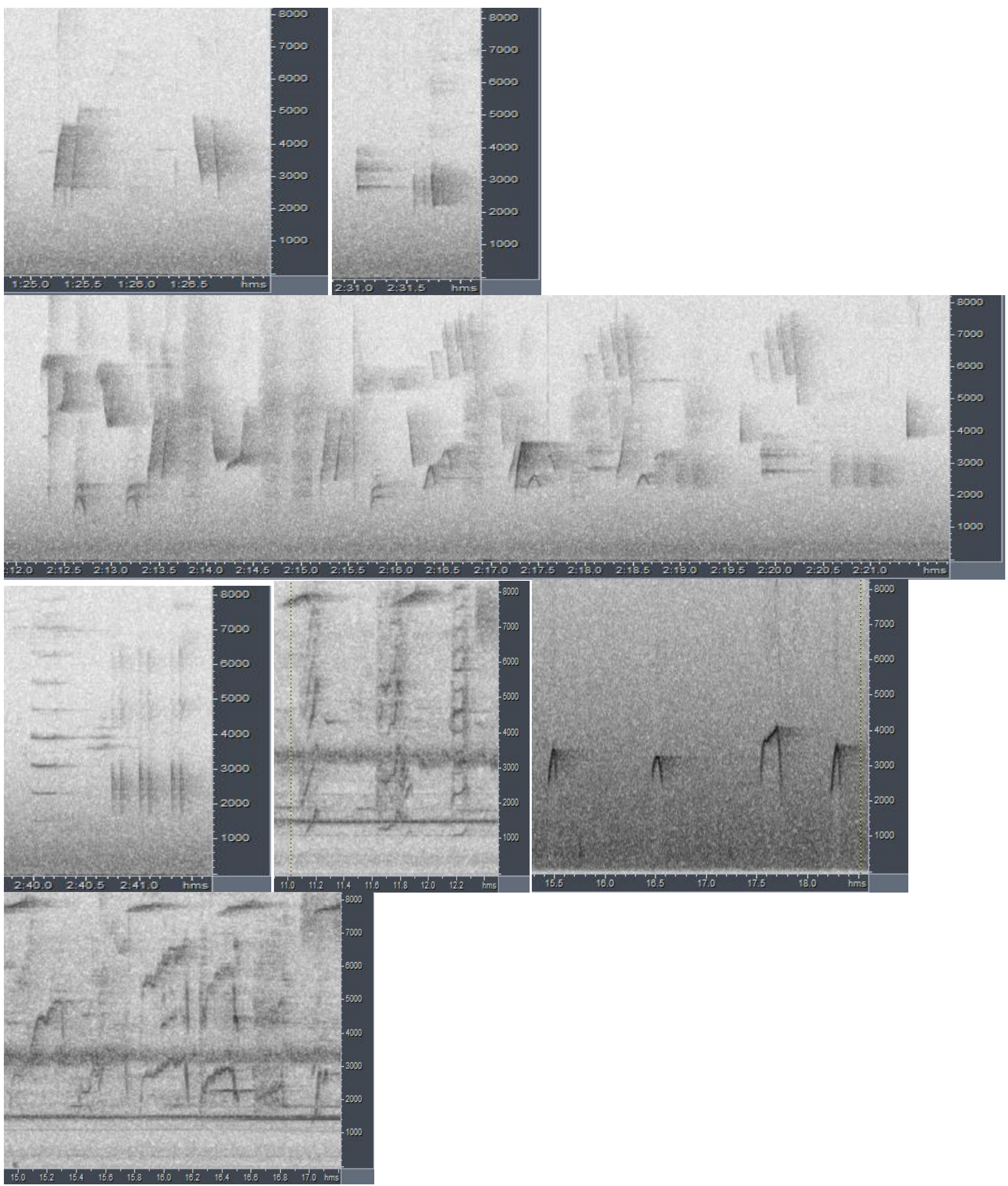


\section{HANDBOOK OF THE \\ BIRDS PF/THE WORLD}

\section{ORNITHOLOGICAL NOTES}

\section{D.h. jentincki (+ faberi)(Java, Bali)}

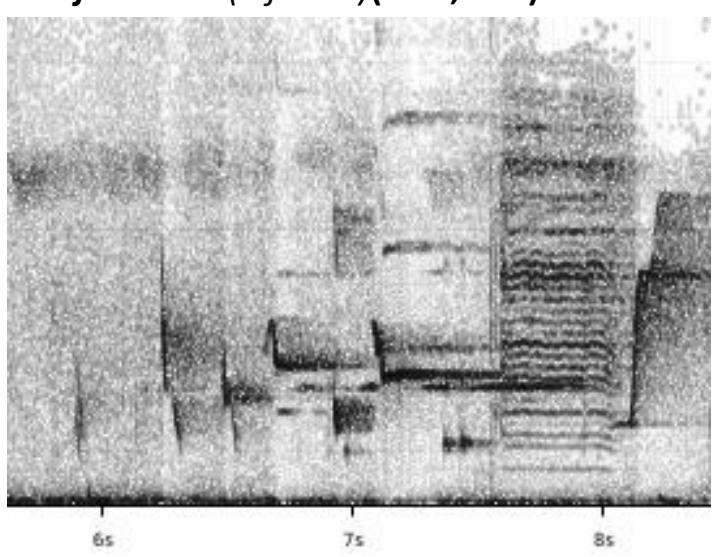

Dicrurus sumatranus (NOT part of D. hottentottus) Sumatran Drongo

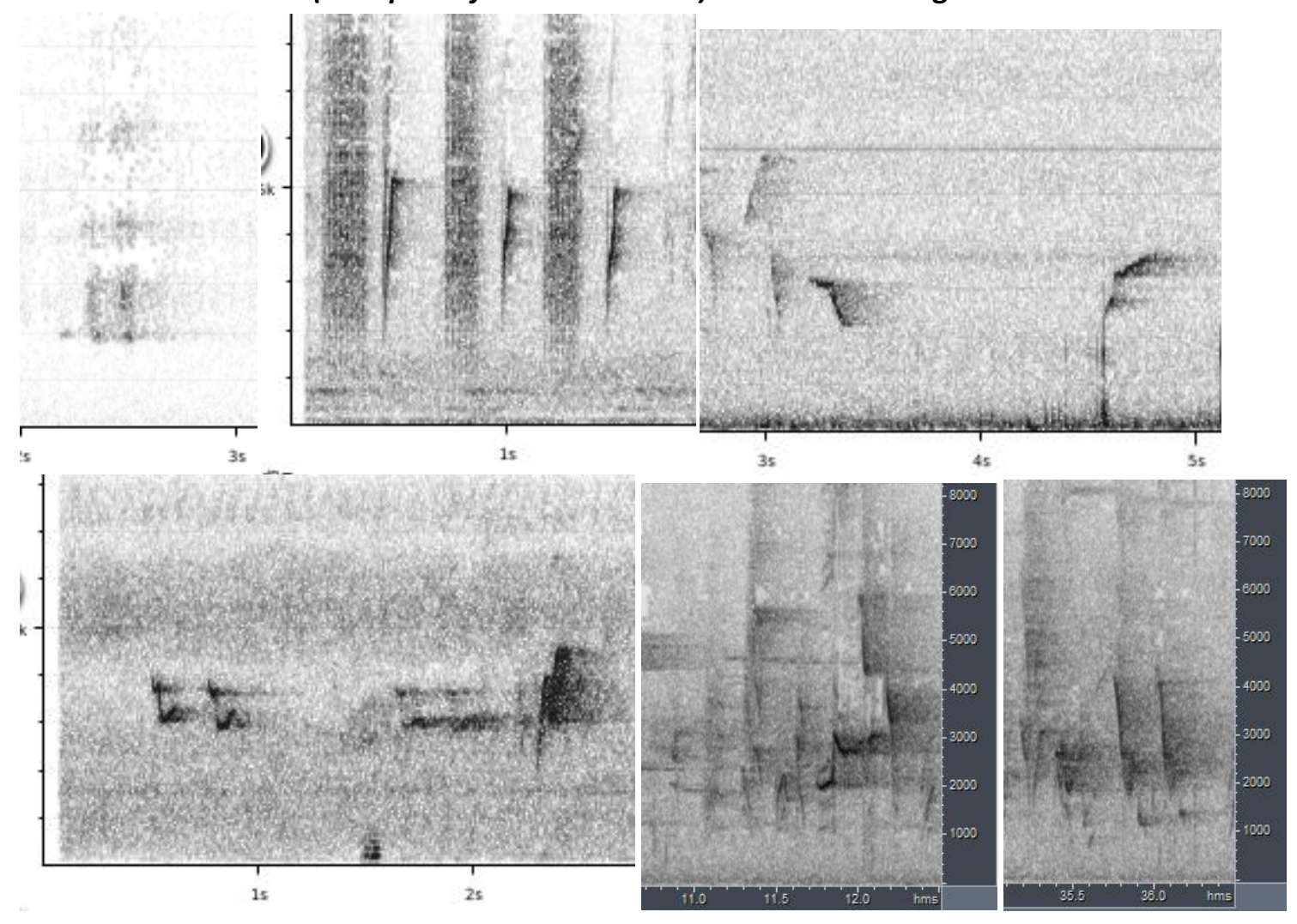

\section{D.h. viridinitens}

No recordings available on-line 


\section{HANDBOOK OF THE

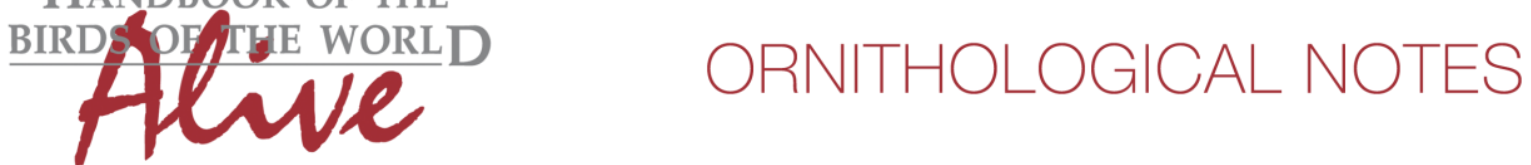

\section{D.h. suluensis (Sulu)}

Tawitawi:
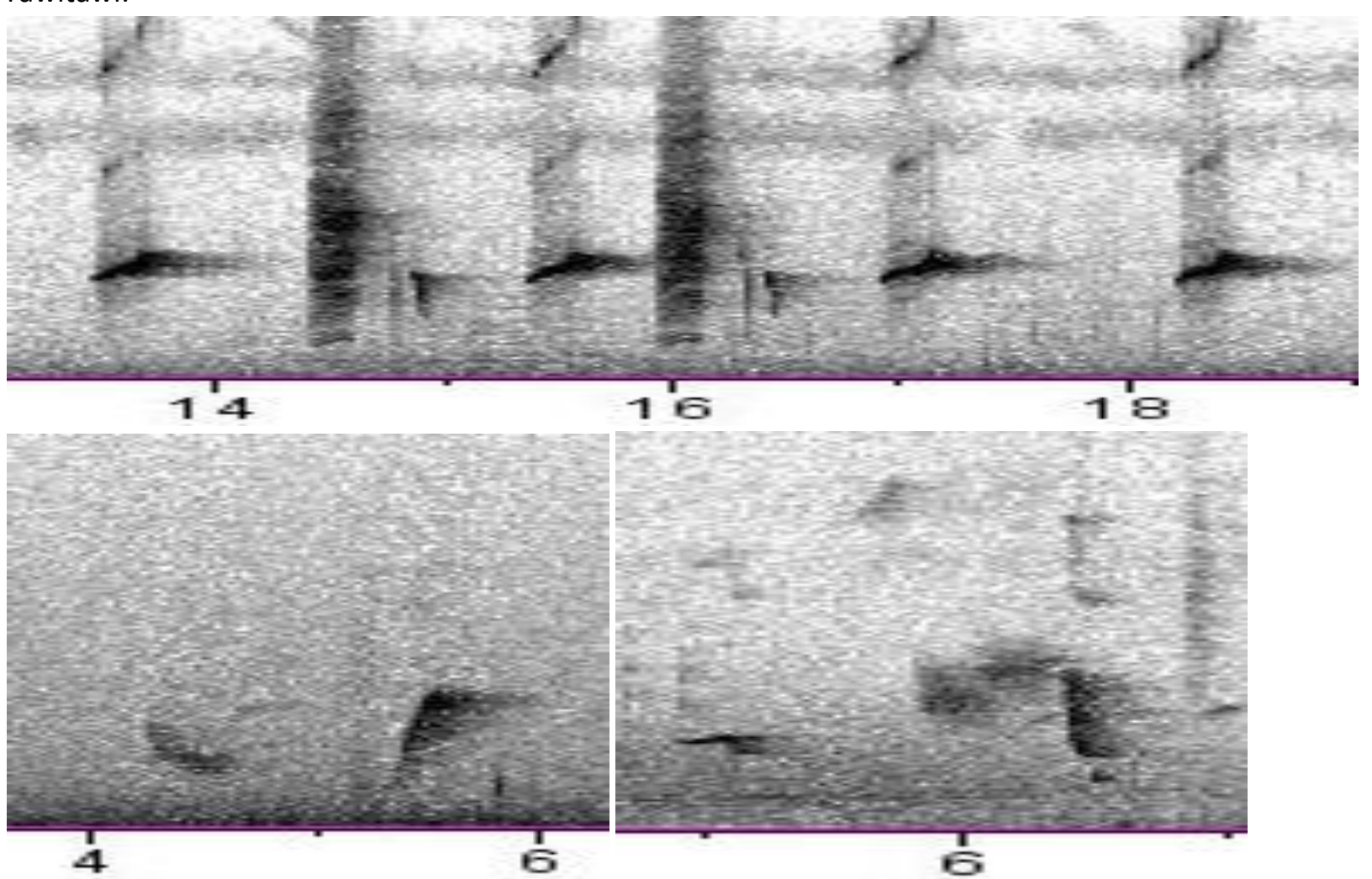

\section{D.h. leucops (+ banggaiensis)}
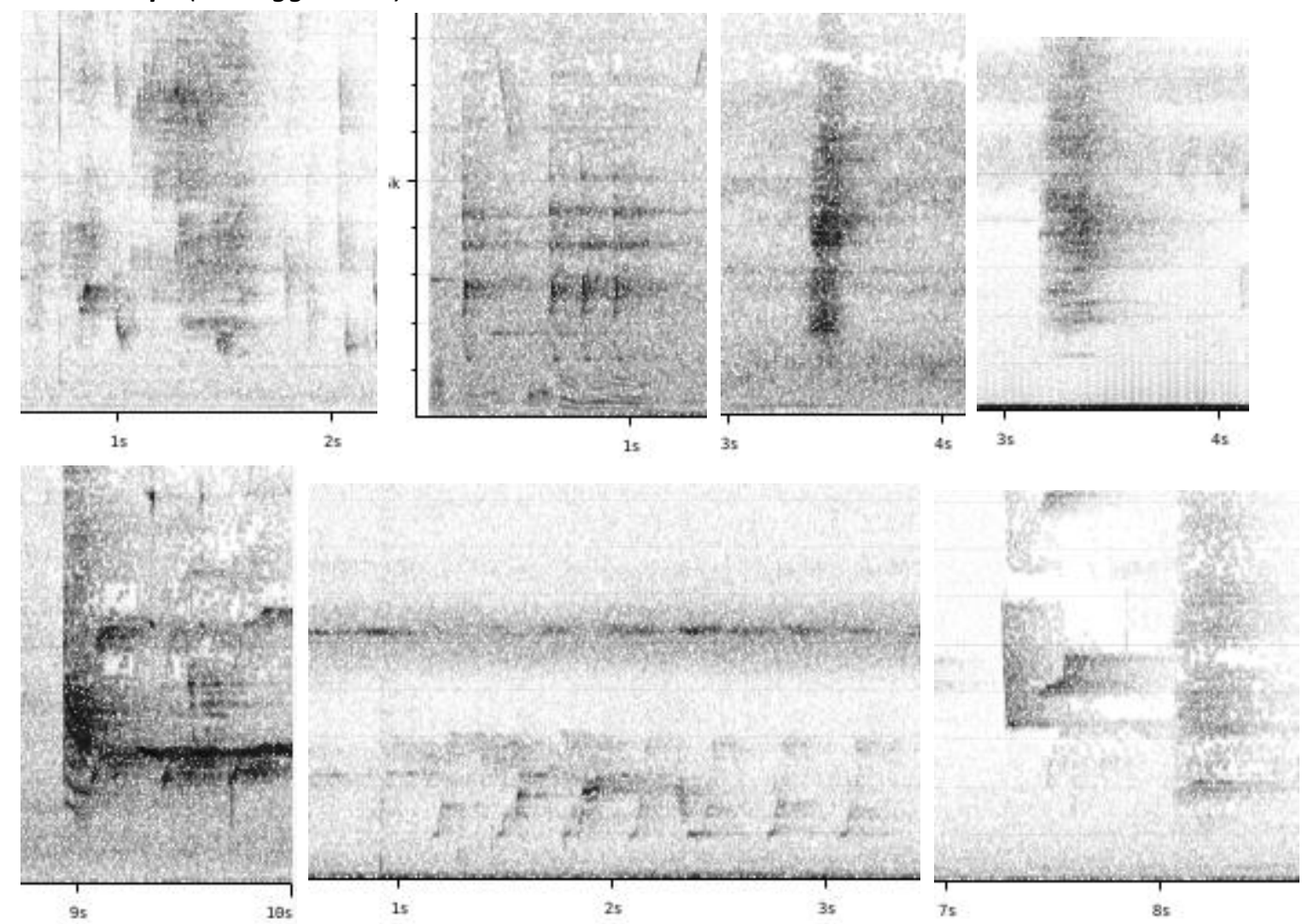


\section{HANDBOOK OF THE Alve
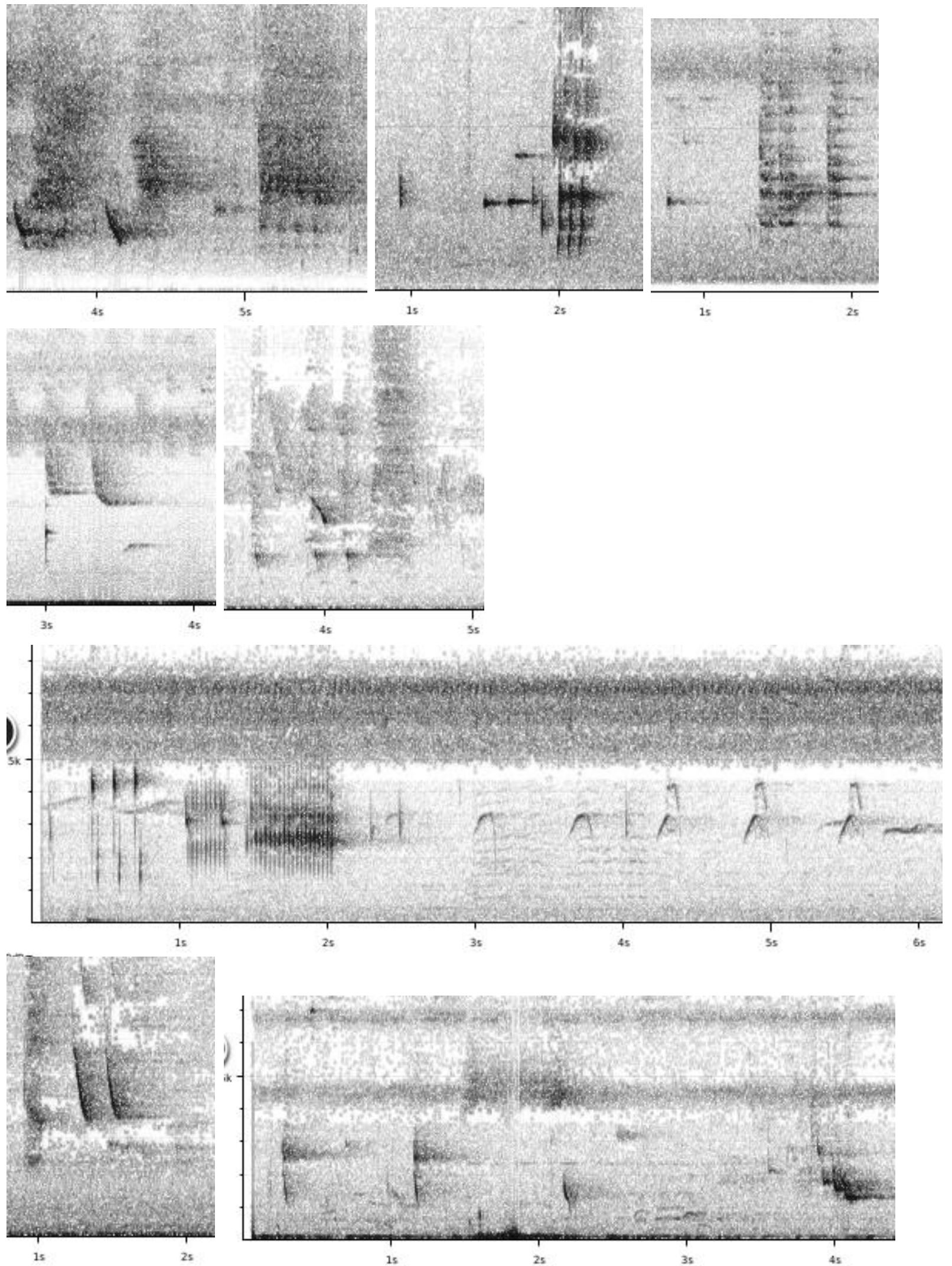


\section{HANDBOOK OF THE \\ BIRDSPFITE WORLD ORNITHOLOGICAL NOTES}
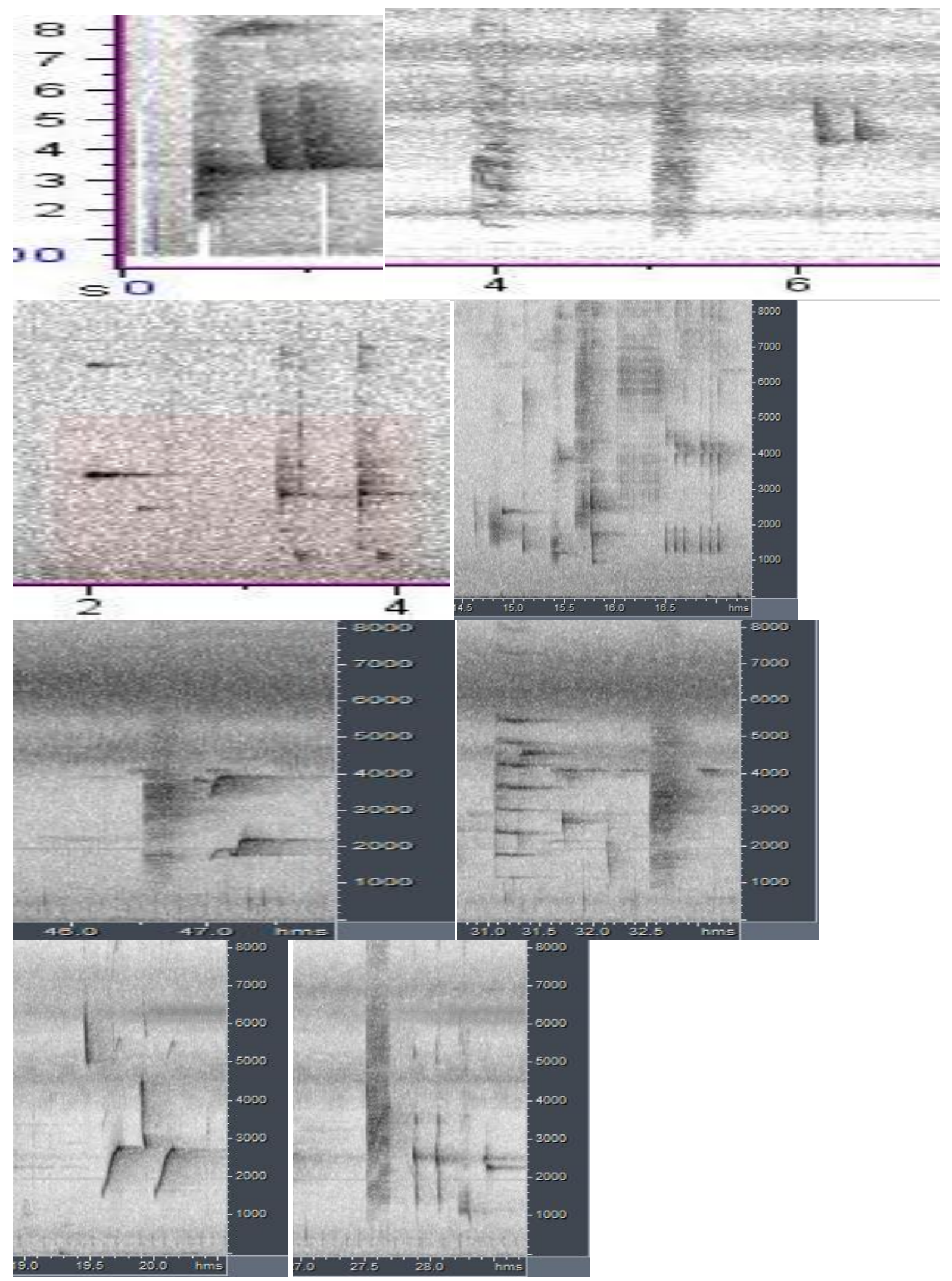
HANDBOOK OF THE

BIRDSPF THE WORLD

ORNITHOLOGICAL NOTES
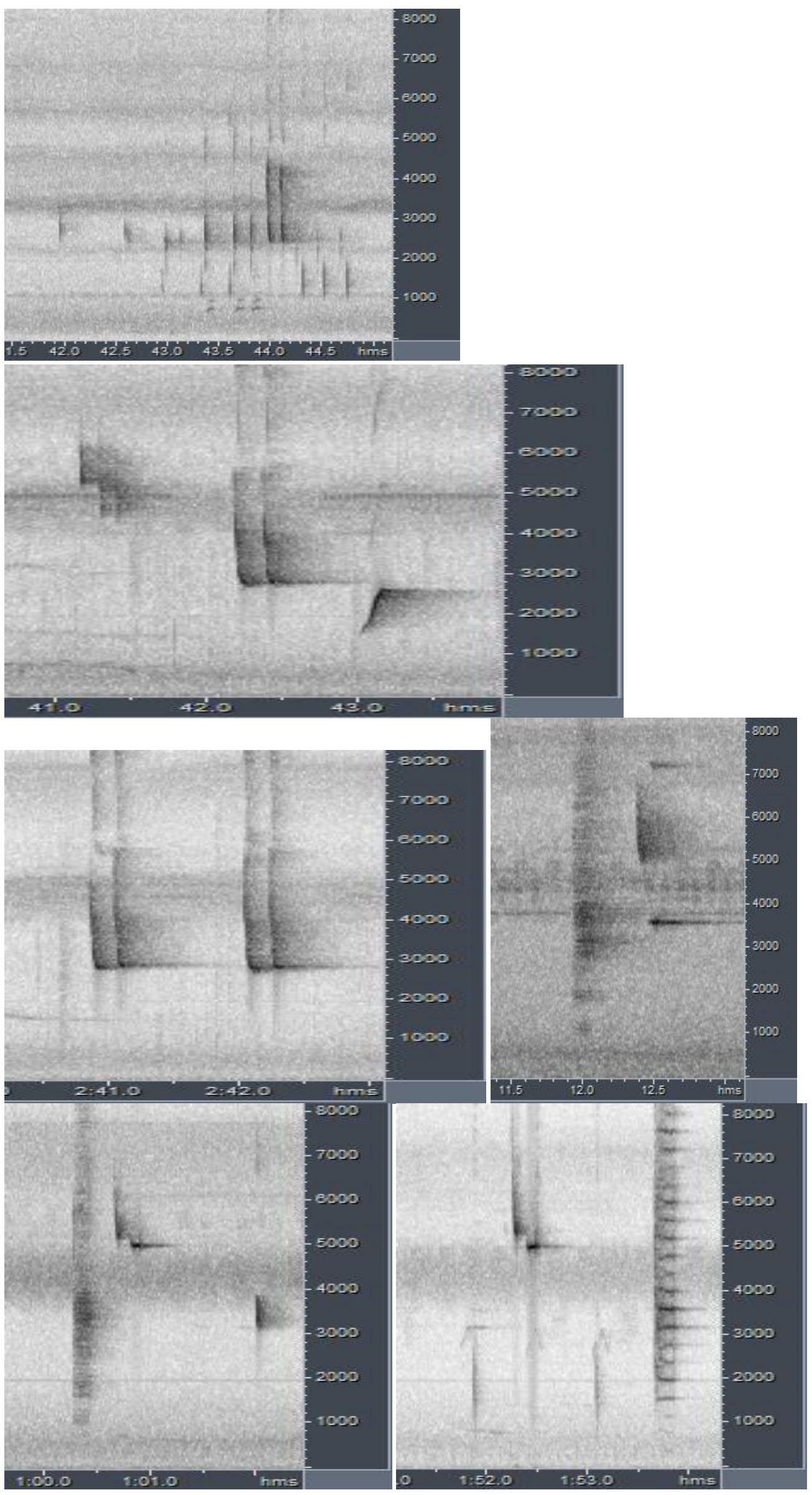

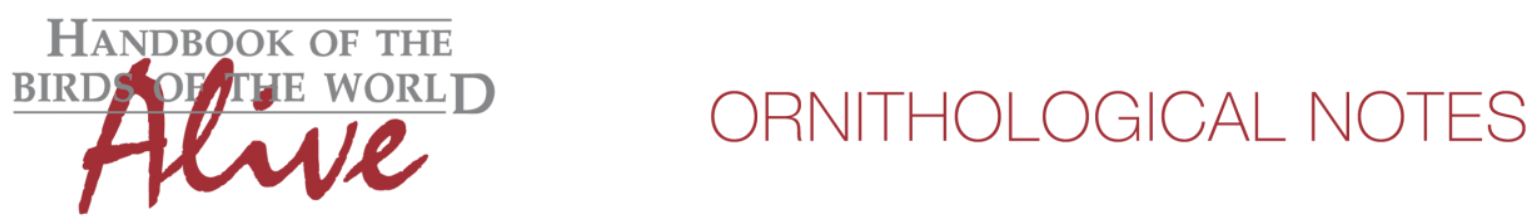

\section{D. montanus (NOT part of D. hottentottus !)(Sulawesi Drongo)}
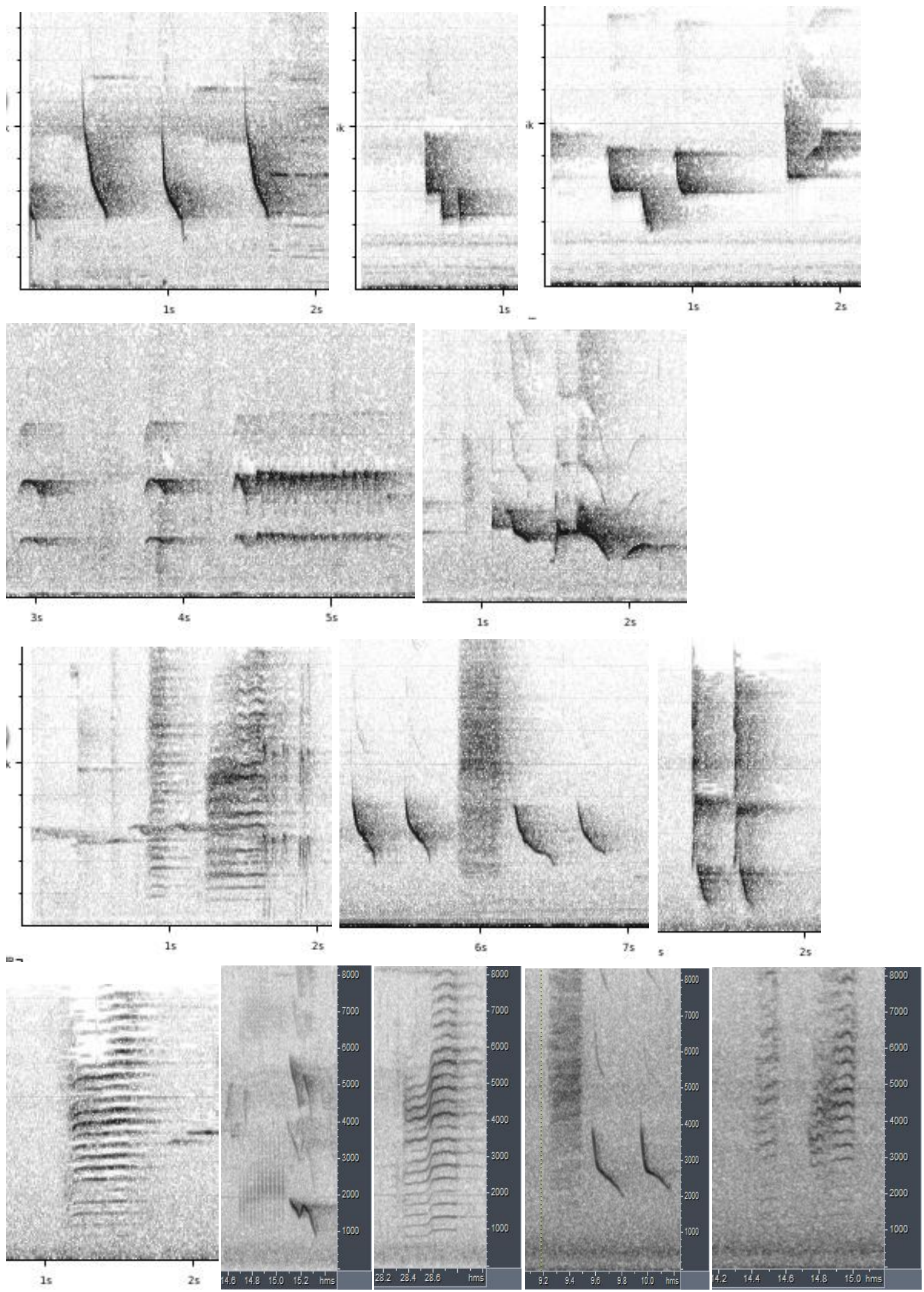
HANDBOOK OF THE

BIRDSPI THE WORLD

ORNITHOLOGICAL NOTES

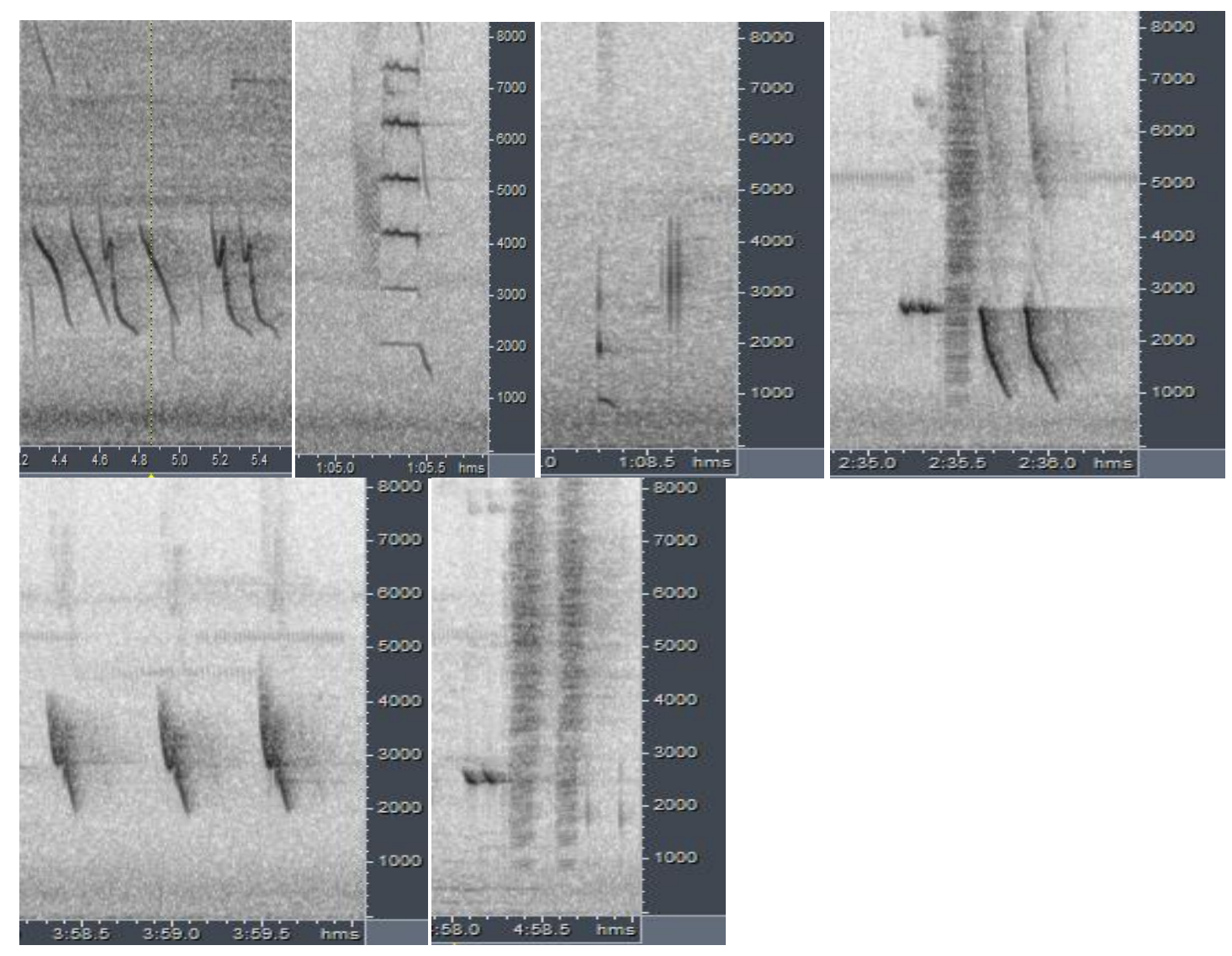

\section{D.h. pectoralis (Sula)}
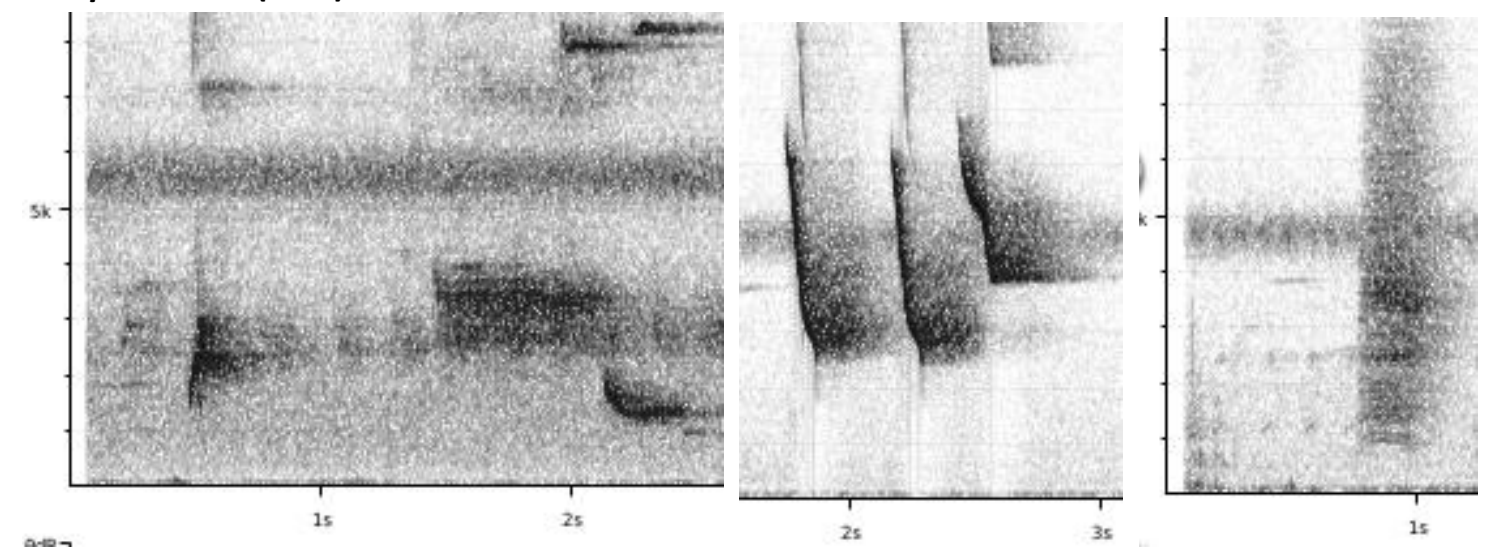
HANDBOOK OF THE

BIRDSPFGE WORLD

ORNITHOLOGICAL NOTES

\section{D.h. guillemardi (Obi)}

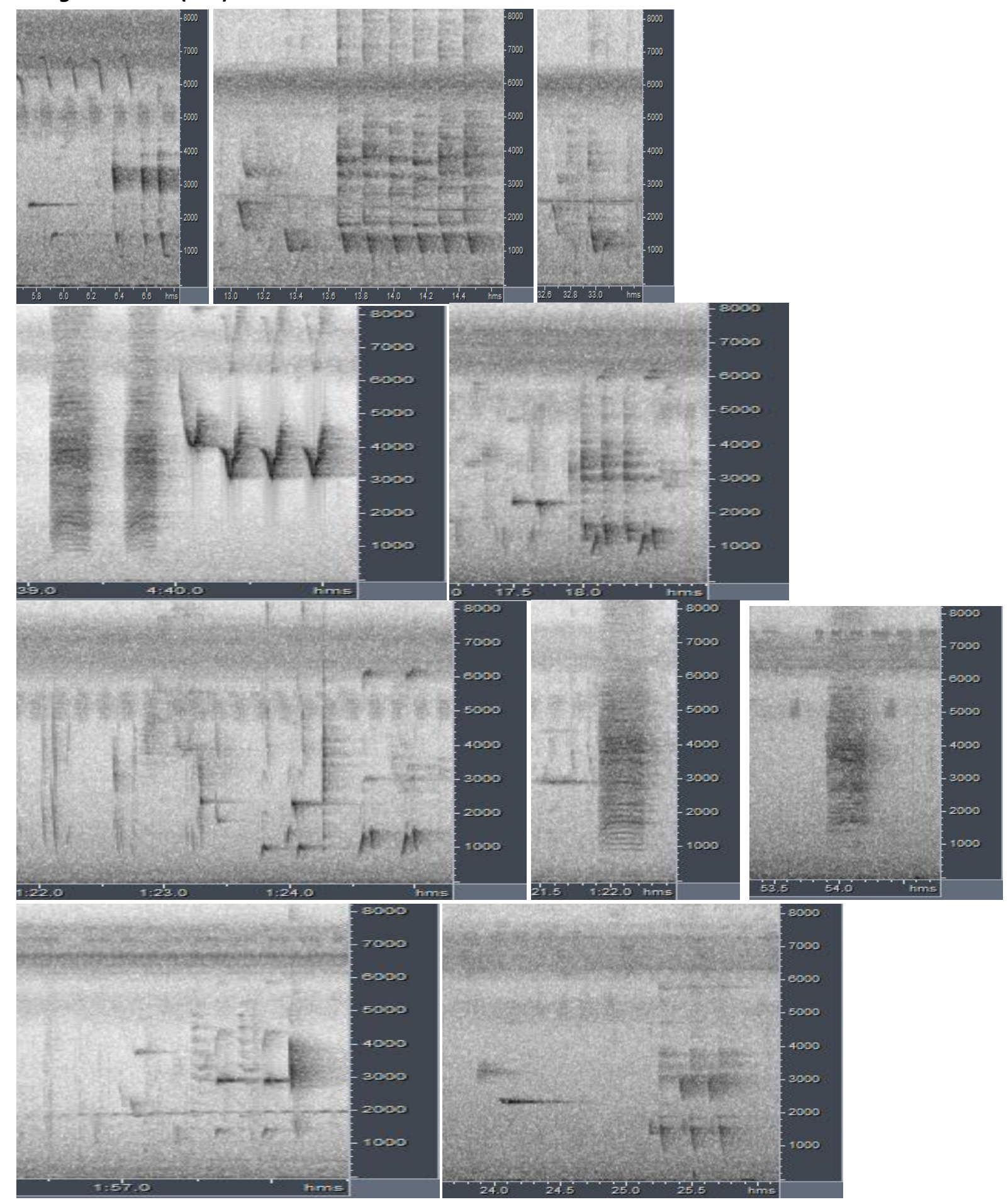




\section{HANDBOOK OF THE \\ BIRDAPlu WORLD ORNITHOLOGICAL NOTES}

D.h. hottentottus + brevirostris (mainland)
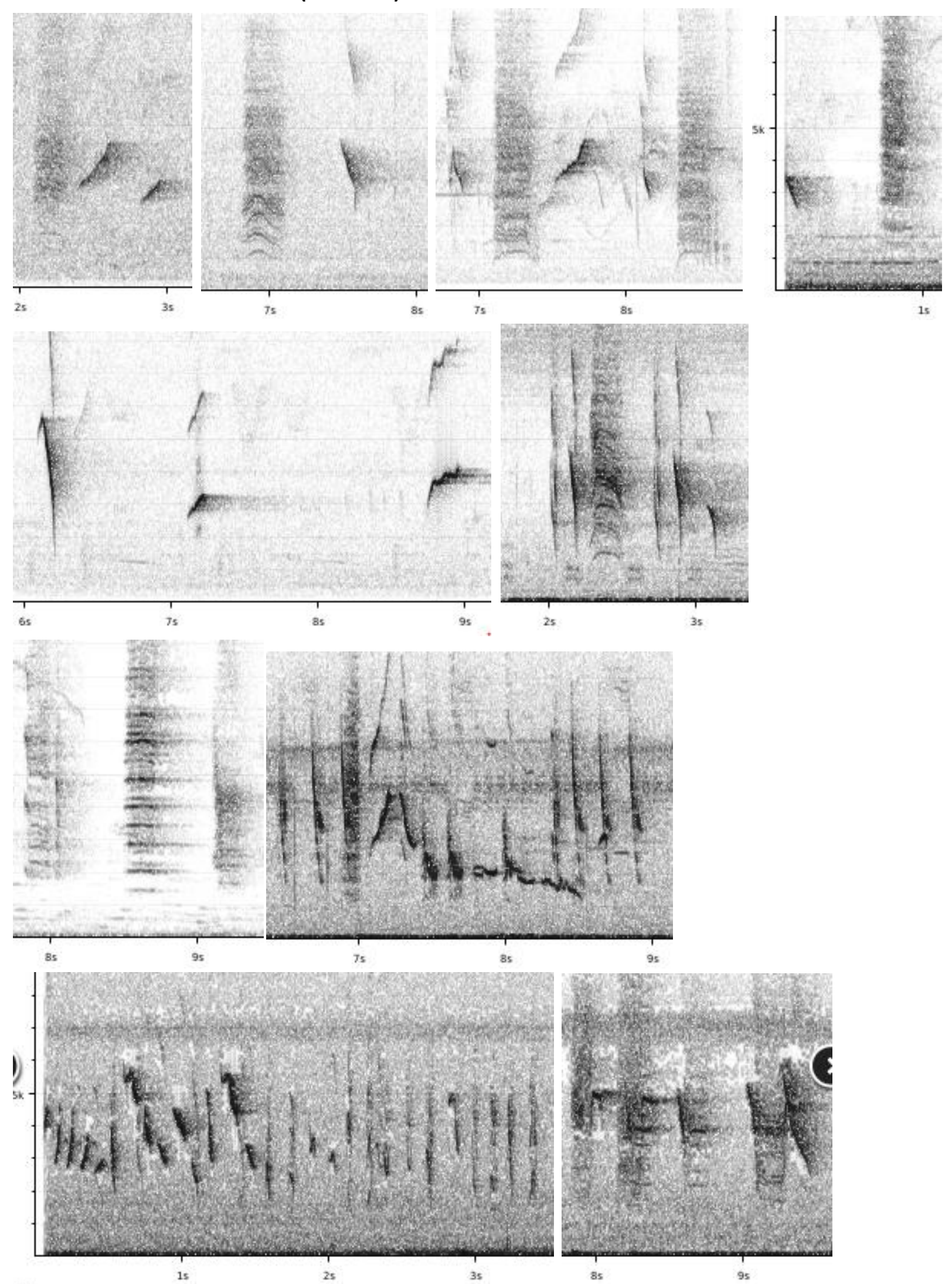
HANDBOOK OF THE

BIRD PF THE WORLD

ORNITHOLOGICAL NOTES
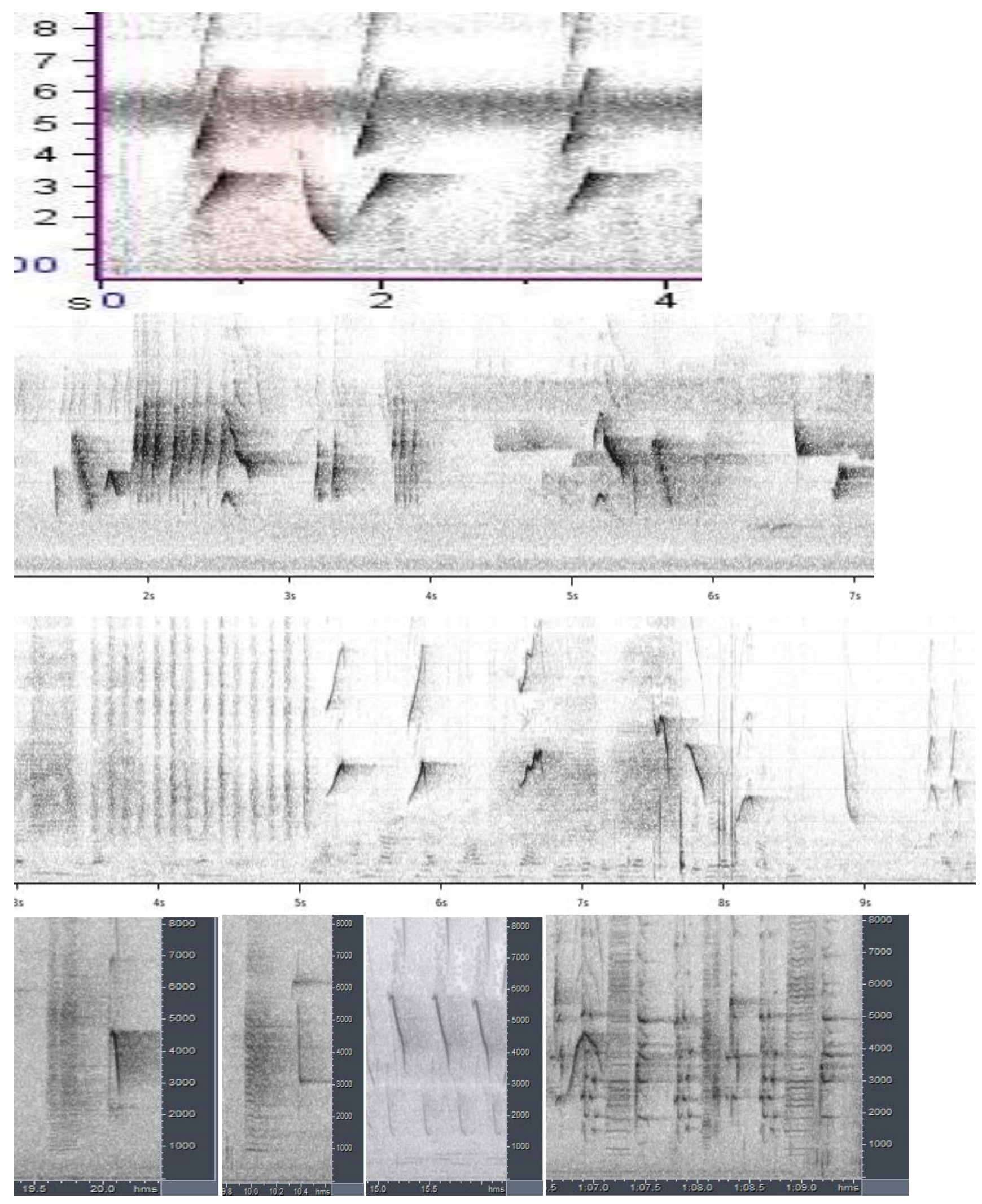


\section{HANDBOOK OF THE \\ Aluve}

\section{ORNITHOLOGICAL NOTES}
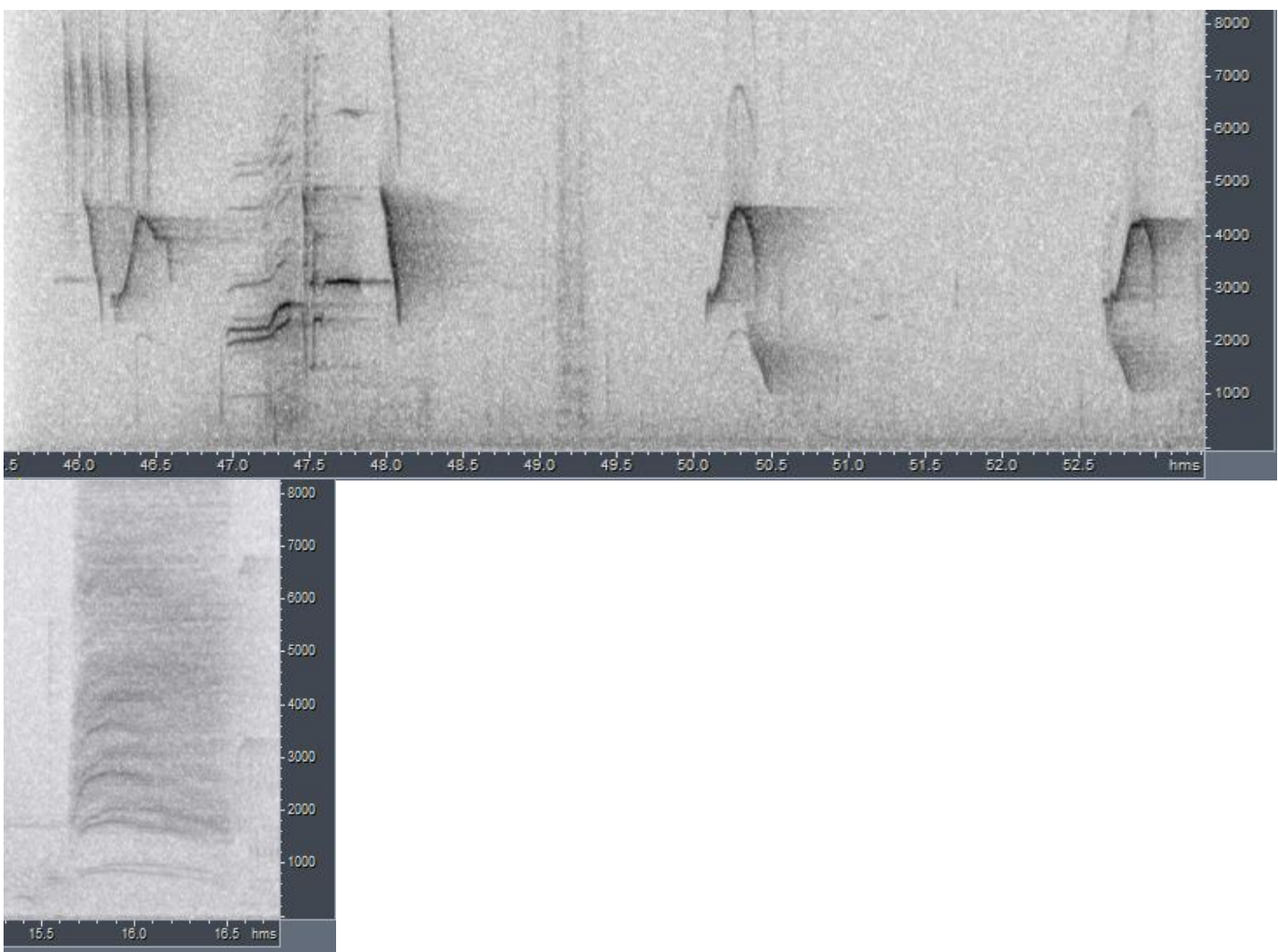

\section{D.h. striatus (S Philippines)}
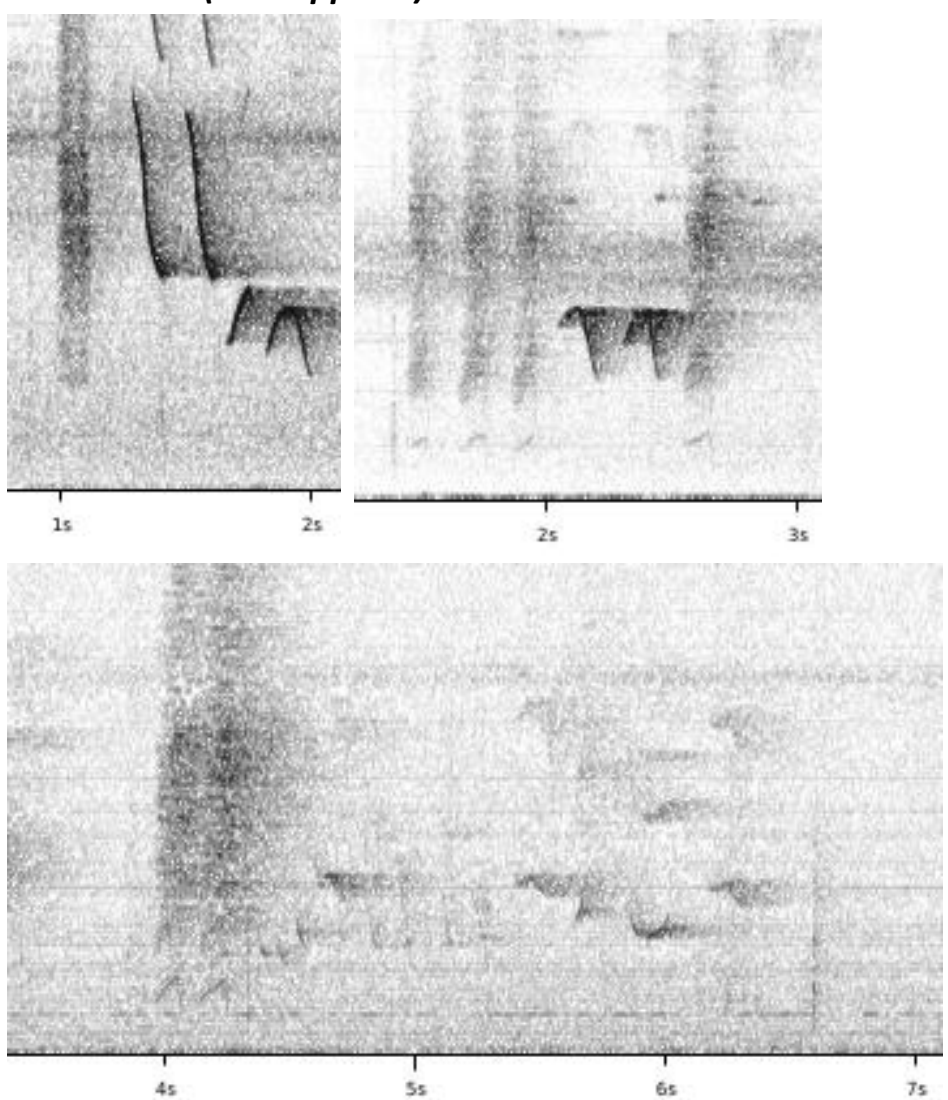


\section{HANDBOOK OF THE \\ BIRDSPFGTE WORLD \\ ORNITHOLOGICAL NOTES}
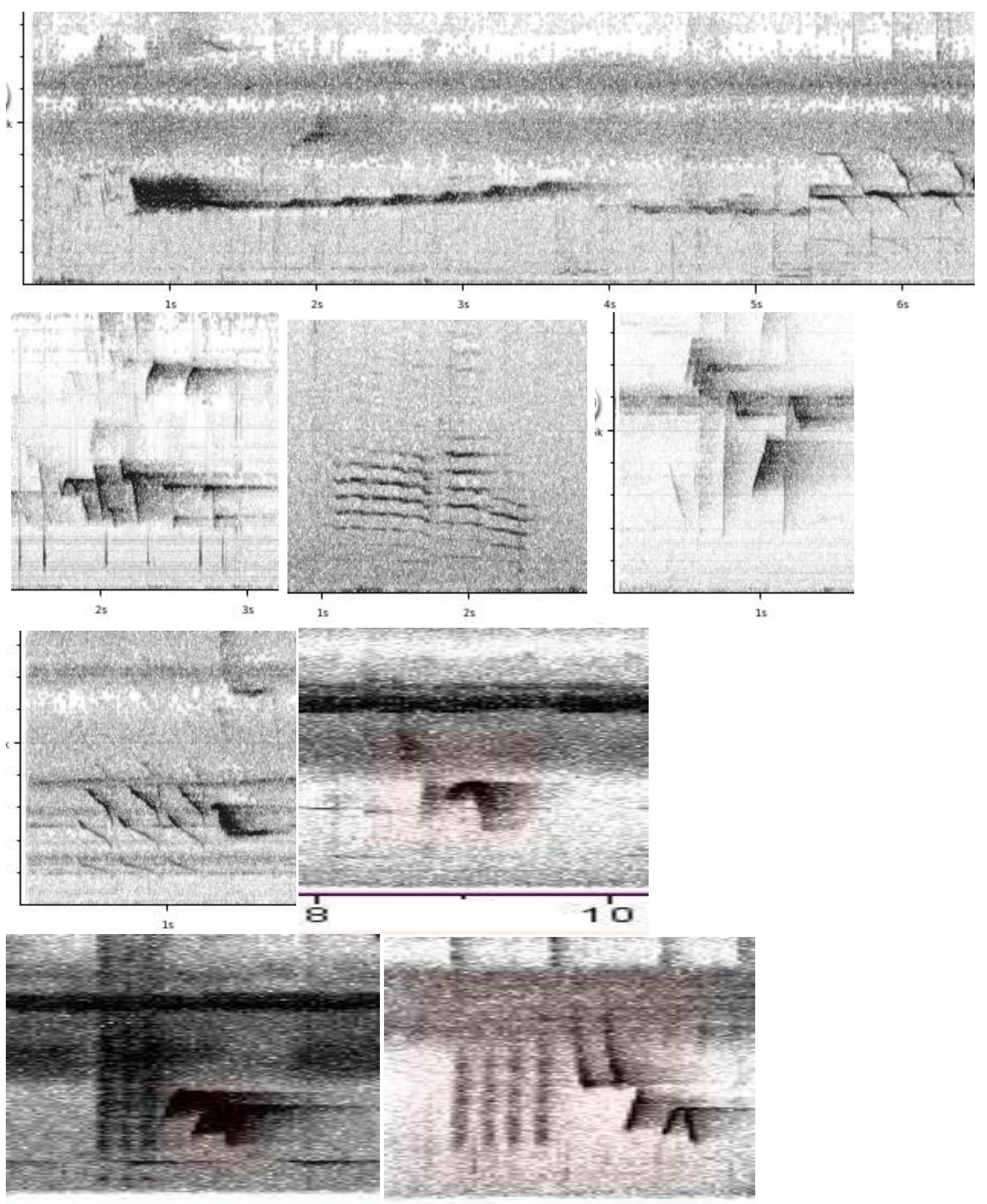

10

12

10 


\section{HANDBOOK OF THE \\ BIRDSPFGE WORLD}

\section{ORNITHOLOGICAL NOTES}
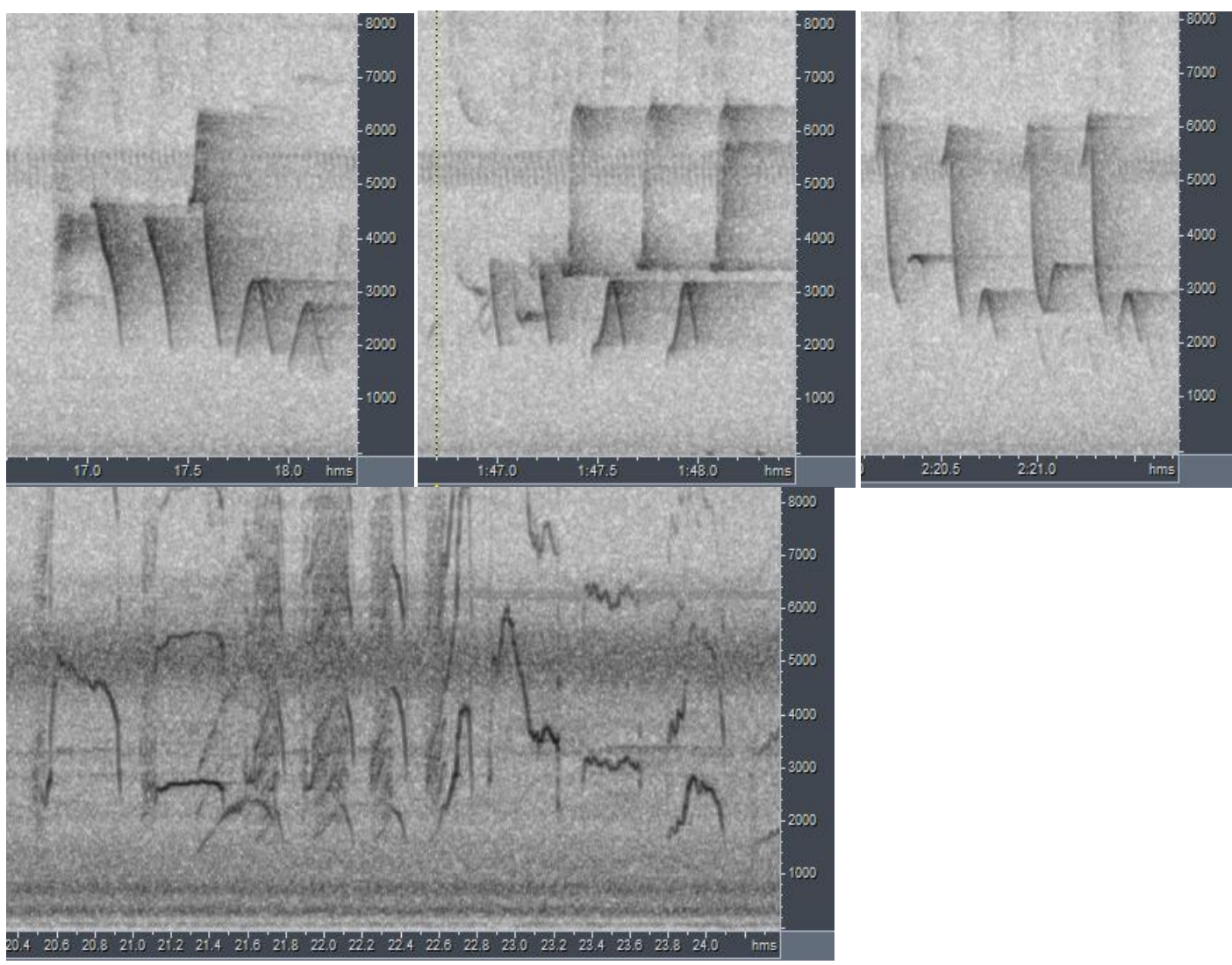

D.h. cuyensis (?) WC Philippines
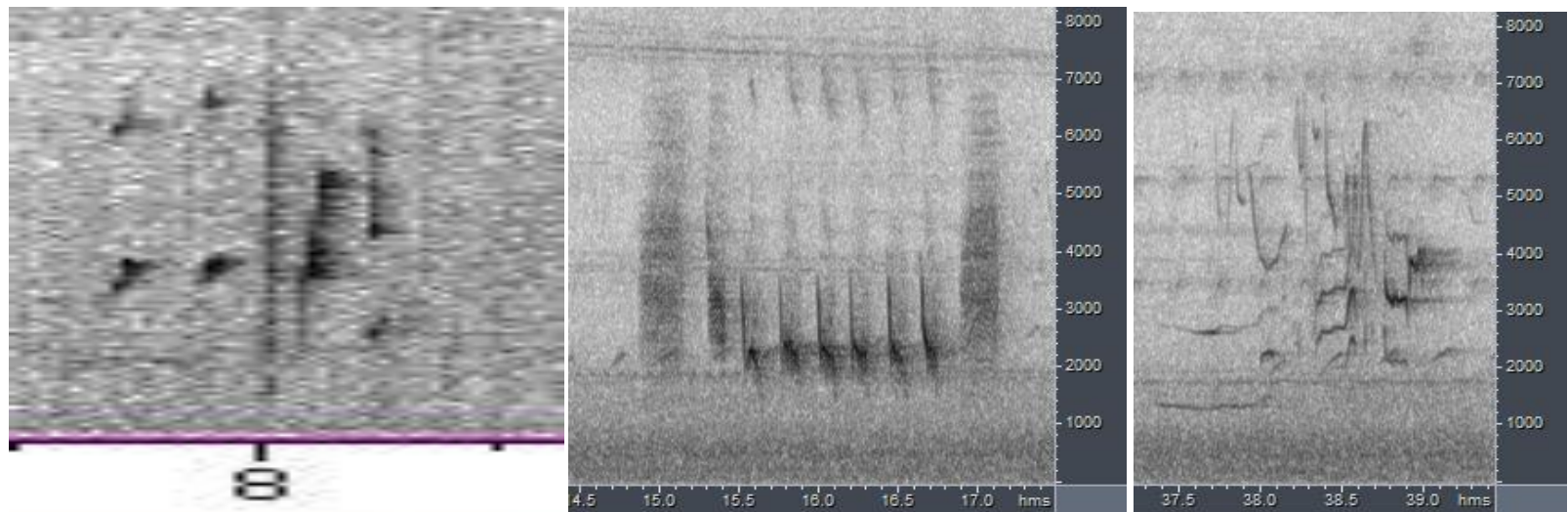

D.h. palawanensis (W Philippines)

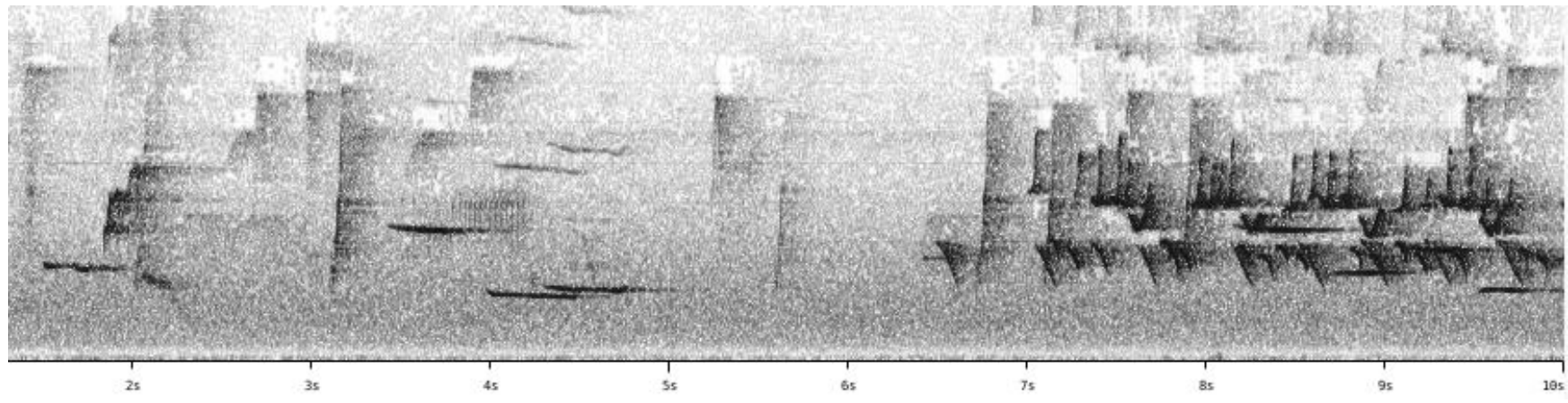


HANDBOOK OF THE

BIRDSPIJUE WORLD

ORNITHOLOGICAL NOTES

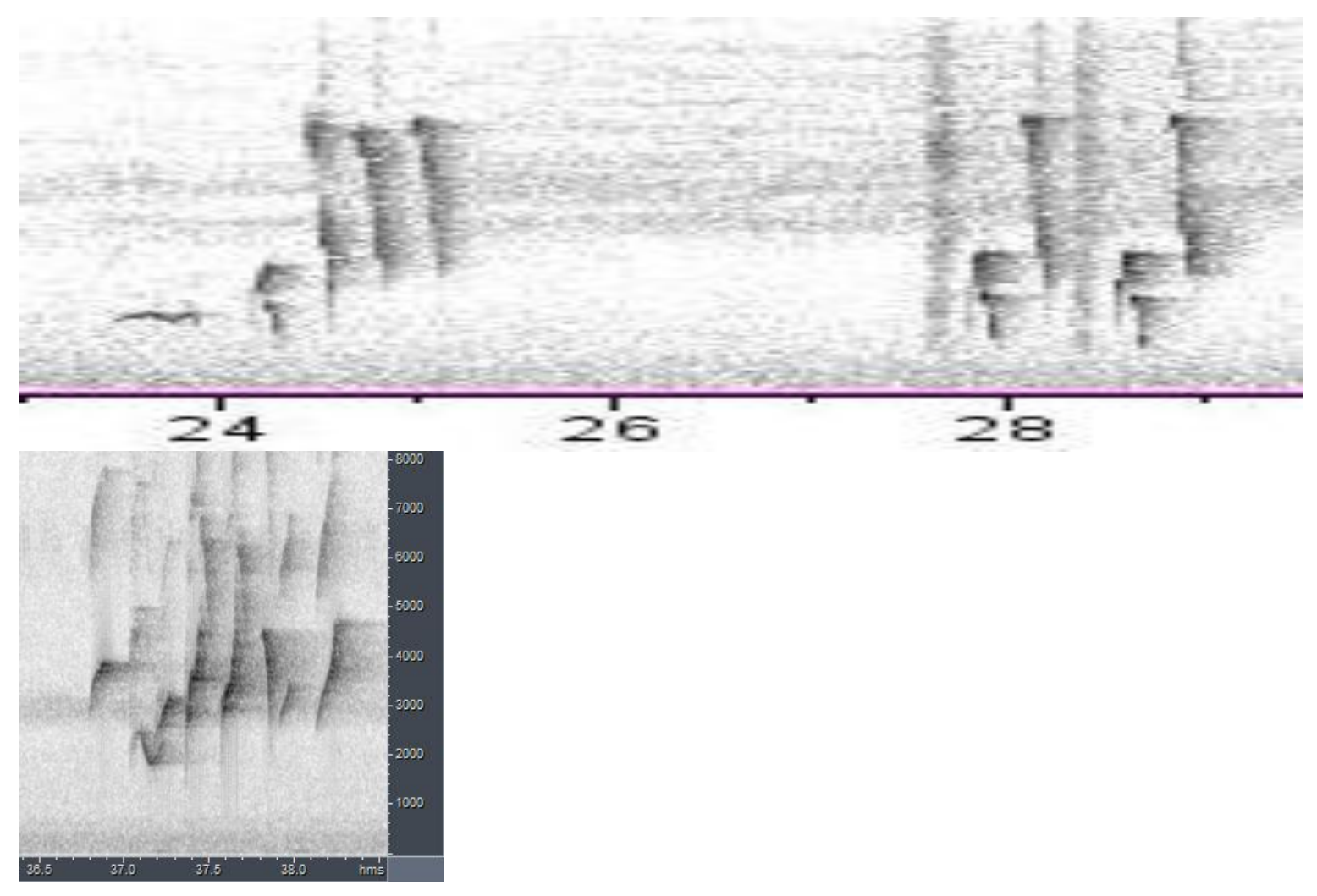

D.h.samarensis EC Philippines
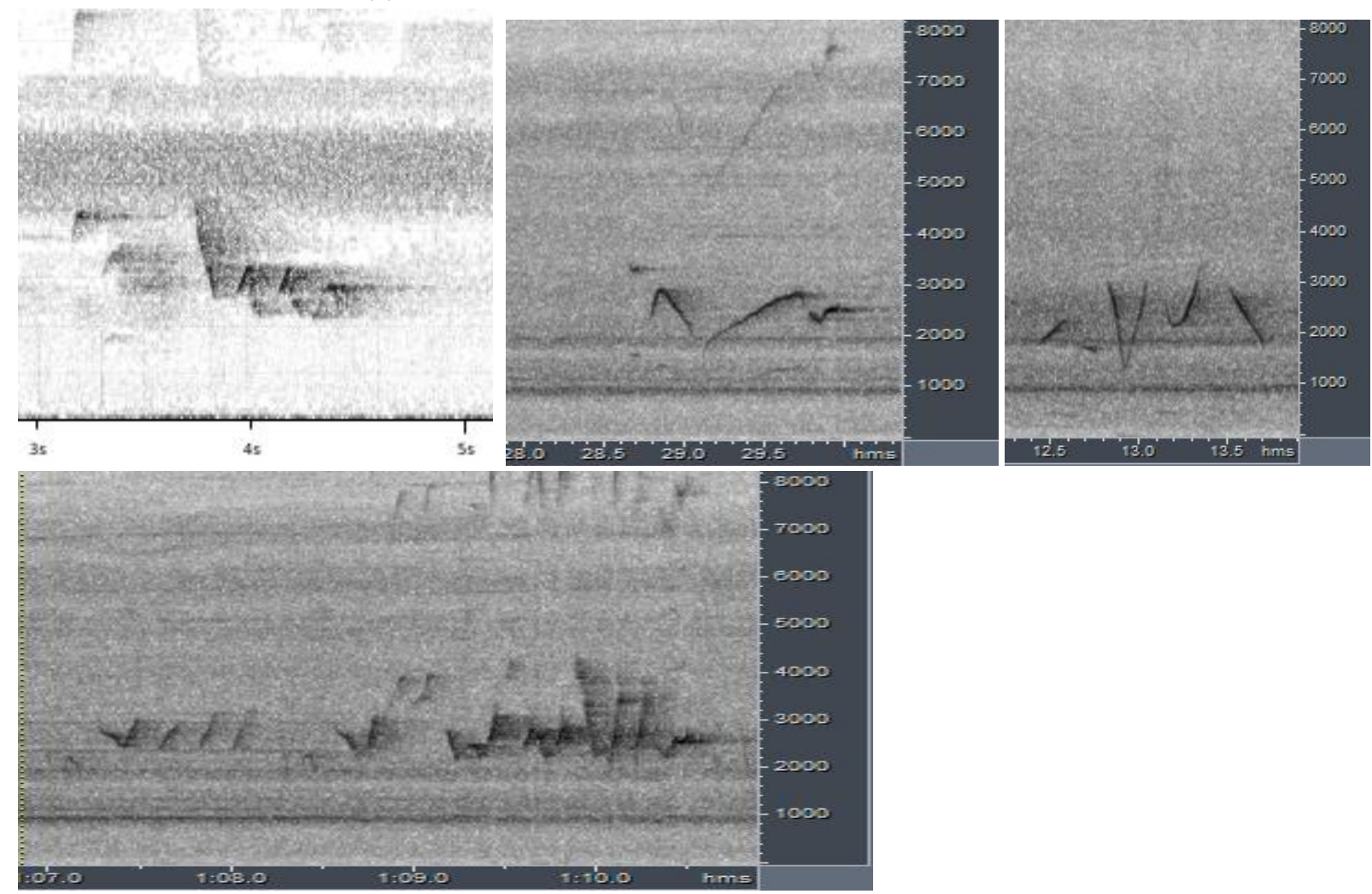
HANDBOOK OF THE

BIRDPPIVE WORLD ORNITHOLOGICAL NOTES

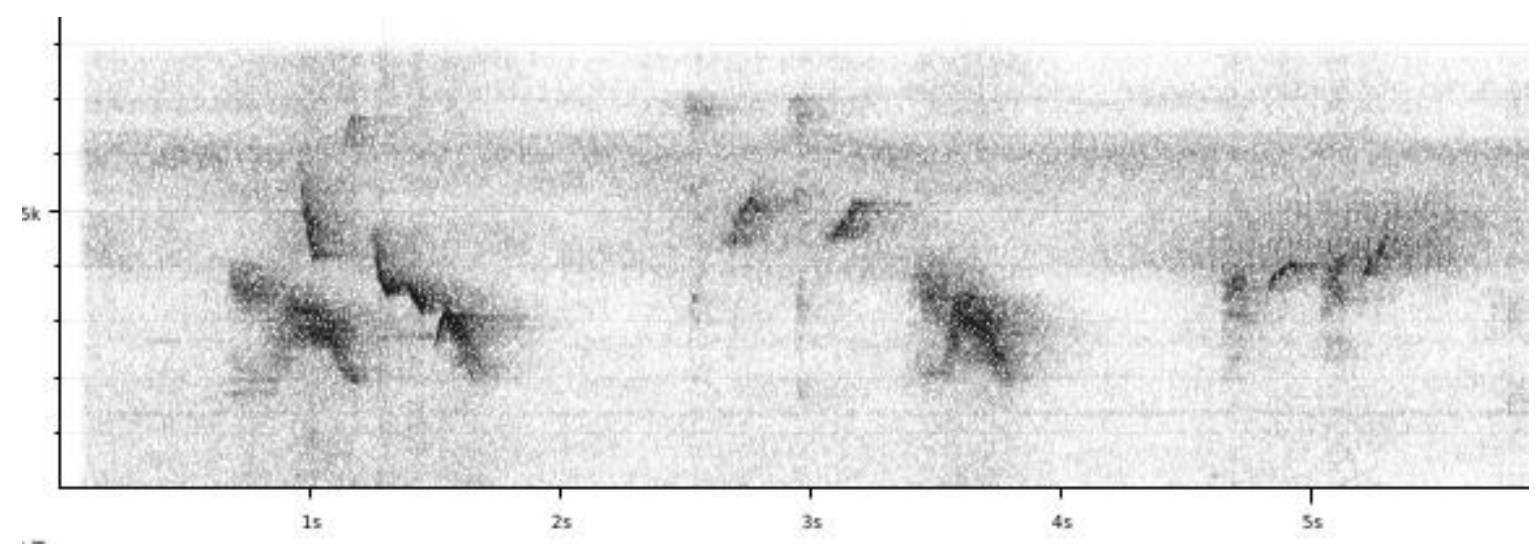

20 